\title{
The Investigation of Teachers' Educational Beliefs and Attitudes towards Democracy and Multicultural Education According to Various Variables
}

\author{
Burak Ayçiçek \\ Ministry of Education, Elazığ, Turkey \\ Tuğba Yanpar Yelken ${ }^{2}$ \\ Mersin University,Mersin, Turkey
}

\begin{abstract}
The aim of the study is to determine the relationship between teachers' educational beliefs and attitudes towards democracy and multicultural education. The data of the study were collected with "Educational Beliefs Scale" and "Democracy and Multicultural Education Attitudes Scale". The sample of this relational survey study consists of 202 teachers working in Antakya district of Hatay province. The findings show that teachers' educational beliefs regarding perennialism and essentialism differ significantly according to gender and seniority variables, and their beliefs regarding existentialism and re-constructionism differ significantly according to school stage variable. The findings of the teachers' attitudes towards democracy and multicultural education show that the teachers' attitude towards multicultural education differ significantly according to gender, school stage and seniority variables, and their prejudiced attitudes towards multicultural education differ significantly according to seniority variable. Significant relationships were found between the teachers' educational beliefs and attitudes towards democracy and multicultural education.

Submitted

20.03.2019

Revised

16.04.2019

Accepted

04.05.2019

Keywords:

democracy and multicultural education educational beliefs

attitude
\end{abstract}

\section{Suggested Citation:}

Ayçiçek, B. \& Yanpar-Yelken T.(2018). The investigation of teachers' educational beliefs and attitudes towards democracy and multicultural education according to various variables, International Journal of Academic Research in Education, 4(1-2), 41-58. DOI: 10.17985/ijare.542132

\footnotetext{
Ministry of National Education, aycicekburak@gmail.com ${ }^{2}$ Mersin University, tyanpar@ mersin.edu.tr 


\section{INTRODUCTION}

The quality of the relationship between teacher and student during the education period affects the quality of education. The main factor affecting this relationship is educational beliefs. According to Kağıtçıbaşı (2006), beliefs are attitudes becoming stable as a result of adoption of a thought towards a specific issue. If any positive or negative attitude is available towards an object or phenomenon, then a positive or negative belief will also be available towards that object or phenomenon mentioned (Tavşancıl 2005). Beliefs identify people's attitudes and behaviors towards environment (Şişman, 2002).

From educational point of view, teachers' beliefs for education as well as their knowledge and skills are important in shaping the system of education. The steps teachers will take pursuant to their educational beliefs significantly affect the quality of education. Educational beliefs take shape with experiences gained throughout education period. The individual's educational belief reflects his/her philosophy or perspective on teaching and learning (Haney, Czerniak and Lumpe, 2003). This shows that educational philosophy is effective in shaping educational beliefs. Teachers' beliefs and behaviors change according to the philosophy of education they have adopted.

The philosophy of education is an approach of thought that can be utilized in the expressions and evaluations of problems (Balcl, 2010). The contents and methods of education, especially educational aims, take shape according to the philosophy that has been adopted (Şişman, 2010). One of the primary aims of the philosophy of education is to arrange and integrate educational beliefs (Brauner and Burns, 1982). From this point of view, it can be said that the main factor that shapes educational beliefs of an individual is philosophy of education. Any educator adopts a philosophy of education, which shapes his/her educational aproach. Accordingly, the quality of education that students get changes depending on the philosophy of education that teachers have (Yılmaz, Altınkurt and Çokluk, 2011). The positon of individuals in the system of education that they have involved in, is determined according to the philosophy of education (Doğanay ve Sarı 2003). In the study, perennialism, essentialism, progressivism, re-constructionism and existentialism were discussed as the philosophies of education defining educational beliefs. These philosophies of education were summarized below (Varış 1994; Şişman 2000; Sönmez 2002; Yayla 2009).

Perennialism refers to a mentality mainly based on idealism. The aim of this philosophy is to train individuals who will grow in physical and spiritual maturity and have mental discipline education. The goals of the education are to improve individuals' mental competences, provide their adaptation to universal and unchangeable reality, teach them to use mental rules correctly and provide their adaptation to a well-disciplined study (Sönmez, 2002).

Essentialism refers to a mentality mainly based on realism. According to the essentialism mentality, an individual gains useful and necessary basic information throughout education period and he can get information through inductive method. According to this mentality, learning is a troublesome process, and well-disciplined study should be preferential. Since teaching precedes learning, teacher is in the center of learning process (Varış, 1994).

Progressivism is the educational reflection of pragmatism, based on the mentality that suggests everything is subject to change. According to this philosophy, reality is a relative concept, and changes continuously. The most prominent feature of this philosophy is to oppose the mentality of training passive individuals, based on the strict discipline of conventional education. Interests, needs and abilities of students should be cared (Şişman, 2000). 
Re-constructionism refers to a mentality based on pragmatic philosophy. Reorganizing the society and creating a world community with common values should be the aim of education. The issues concerning the future of society should be included in educational programs. There should be a democratic learming environment in schools and punishment shouldn't be imposed in education (Yayla, 2009).

Existentialism is the reflection of existential philosophy on education. In existentialism, the knowledge is acquired through intuitions. Human being creates its own existence and values, which shows that human is a free being. The main purpose of existentialist education is to underline the importance of freedom in individual's life and raise his awareness about the importance of making a choice (Yayla, 2009).

Each of the philosophies of education, briefly expressed above, have distinctive characteristics. The roles of student and learning environments change in each mentality of philosophy. The perennialism and essentialism philosophies are based on teacher centered conventional education, the others are based on the student centered contemporary education (Demirel, 2006).

Education and democracy are interrelated concepts. According to Büyükkaragöz and Çivi (1998), education is one of the important factors required for democracy to exist. Besides, democratical practices and thoughts are important in the development of education. According to Collins and O'Brien (2003), democratical education is a form of education that enables the development of critical thinking skills and the principles of democracy.

The aim of democracy education is to train citizens who know and adopt human rights and freedoms (Gözütok, 2007).Training citizens who adopt democratical attitudes and behaviors is among fundamental objectives of democracy education. A good citizen in modern democratical communities is defined as a person who can think independently, use scientific methods to solve problems and act honestly to himself. Democracy education aims to make individuals aware of their duties and responsibilities (Büyükkaragöz and Çivi, 1998). Additionally, democracy education enables individuals to participate in social life actively (Yeşil, 2002).

It can be said that an education environment, where a teacher is only person who decides, doesn't comply with the nature of a democratical learning environment. Indeed, Gözütok (2007) states that democracy education makes sense only in case of being given in democratical environments, otherwise, it will be uneffective and temporal. Büyükkaragöz (1990) underlined that giving democracy education in schools theorically will be insufficient, and on the contrary, democracy should be turned into a life style so as to interiorize democracy.

The adoption of democratical and modern education philosophies is very important in the formation of multicultural education environment. In terms of providing multicultural education for society, a multicultural teaching environment can be created in classrooms, and such an environment can be enriched by developing new teaching strategies and techniques (Banks, 2013). Moreover, Ameny-Dixon (2004) regards multicultural education as a learning, teaching approach based on democratical values. According to Yoon (2012), multicultural education develops democratic attitudes and values of students from different cultures and guarantees learning and teaching rights of students.

Some researchers regard multicultural education as a reform that gives equal education opportunity to students with different races, colours, ages, genders, social and economic status, languages, religions (Aydin, 2013; Banks, 2013; Gay, 1994). According to Bank (2013), prejudices towards differences decrease with multicultural education and a positive communication environment can be created with concepts such as mutual targets, respect and appreciation.

There is a strict relationship between multicultural education and curriculum. An curriculum mentality that gives importance to differences creates a democratic environment. Banks (2012) emphasizes the 
importance of raising awareness that cultural, national and religious identities are interrelated concepts. Kridel (2010) states that multicultural curriculum consists of an important aspect of curriculum development.

Teachers have duties and responsibilities in giving multicultural education. They are supposed to have improved cognitive, affective and psychomotor skills for multicultural education (Unlu and Orten, 2013). In this context, according to Sharma (2005), a teacher is a decision maker in the formation of learning environment, for this reason, he has an important positon as a role model.

The examination of teachers' educational beliefs and attitudes towards democracy and multicultural education can give clues about what extend requested changes can be actualized in educational environments. Also, teachers' attitudes towards democracy and multicultural education can be determined on the basis of their educational beliefs. Determining teachers' educational beliefs and attitudes towards democracy and multicultural education, and examination of their relationships with various variables is necessary and important to express teachers' behaviors.

\section{Purpose of the study}

The purpose of the study is to determine the relationship between teachers' educational beliefs and attitudes towards democracy and multicultural education according to "gender, school stage, and professional seniority" variables. The following questions are sought for this purpose.

1. What are the teachers' educational beliefs?

2. What are the teachers' attitudes towards democracy and multicultural education?

3. Is there any significant relationship between teachers' educational beliefs and attitudes towards democracy and multicultural education?

4. Do teachers' educational beliefs differ significantly according to "gender, school stage, and professional seniority" variables?

5. Do teachers' attitudes towards democracy and multicultural education differ significantly according to "gender, school stage, and professional seniority" variables?

\section{METHOD}

This study is a descriptive one conducted using survey model so as to identify the current situation. A survey model is an approach of research that aims to describe a situation as it is, existing currently or existed in the past (Karasar, 2000).

This study was designed in relational survey model to determine the relationship between teachers' educational beliefs and attitudes towards democracy and multicultural education according to some variables. Relational survey model is defined as a research model that aims to determine the presence or degree of correlation between two or more variables (Karasar, 2009).

\section{Study Group}

The data of the study were obtained from 202 teachers working in Antakya district of Hatay province. The teachers in the study group were selected through convenience sampling. Convenience sampling is a type of nonprobability or nonrandom sampling where members of the target population that meet 
certain practical criteria, such as easy accessibility, geographical proximity, availability at a given time, or the willingness to participate are included for the purpose of the study (Dörnyei, 2007).

$55,4 \%$ of the participant teachers are females $(n=112), 44,6 \%$ are male $(n=90) .26,2 \%$ are working in primary schools $(n=53), 41,6 \%$ in secondary schools $(n=84), 32,2 \%$ in high schools $(n=65) .42,1(n=85)$ $\%$ of 202 participant teachers have a seniority between $1-10$ years, 35,1\% ( $n=71)$ between 11-20 years, $22,8 \%(n=46)$ have a seniority of 21 years and more.

\section{Data Collection Tools}

A. Democracy and Multicultural Education Attitude Scale (DMEAS): The democracy and multicultural education attitude scale used in the study was developed by Toraman, Acar and Aydin (2015). DMEAS was developed so as to determine teachers' attitudes towards democracy and multicultural education. DMEAS consists of 5 subscales and 27 items. These sub-scales are; Attitude Towards Multicultural Education, Prejudiced Attitude Towards Multicultural Education, Attitude Towards Democracy Education, Attitude Towards Democracy and Attitude Towards Cultural Differences. It was determined that these subscales's Cronbach's Alpha reliability coefficient was between 0.706 and 0.829 . KMO value was found as 0.794 and Bartlett Test was found as $\left(\chi^{2}=1478,378 ; p<0.01\right)$. Exploratory factor analysis was applied to examine construct validity of "Democracy and Multicultural Education Attitude Scale". It is seen that factor load values vary from 0.376 to 0.729 . Also, item total correlations show different values between 0.198 and 0.622 . The variance that the items explain under five factors is $\% 56.732$

The DMEAS used in the study was designed in the form of 5 point likert scale ranking from "I certainly agree" to "I certainly disagree". These subscales and their associated items are as follows:

- Attitude Towards Multicultural Education: It consists of items no 12, 17, 23, 24, 25, 26 and 27. The highest point that can be obtained from this subscale is 35 . Getting high score indicates positive attitude towards multicultural education.

- Prejusticed Attitude Towards Multicultural Education: It consists of items no 5, 13, 14, 16, 18, 19 and 20.The items in this subscale are those either with negative verb or negative meaning. Therefore, they are reversely scored. The highest score that can be obtained from this subscale is 35 . Getting high score indicates unprejudiced attitude, low score indicates prejudiced attitude.

- Attitude Towards Democracy Education: It consists of items no 2, 3, 4 and 6. The highest score that can be obtained from this subscale is 25 . Getting high score shows positive attitude towards democracy education.

- Attitude Towards Democracy: It consists of items no 7, 8, 9, 21 and 22. The highest score that can be obtained from this subscale is 25 . Getting high score indicates shows positive attitude towards democracy.

- Attitude Towards Cultural Differences: It consists of items no 10, 11 and 15. The highest score that can be obtained from this subscale is 15 . Getting high score indicates positive attitudes towards cultural characteristics and differences.

B. Educational Beliefs Scale (EBS): The educational beliefs scale used in the study was developed by Yılmaz, Altınkurt and Çokluk (2011). EBS was developed to determine teachers'educational beliefs.

Explanatory and confirmatory factor analyses were conducted for construct validity of the scale. As a result of explanatory factor analysis, factor load values of the scale were calculated as $0.50-0.73,0.58-$ $0.74,0.52-0.68,0.42-0.61$ and $0.61-0.73$ for progressivism, existentialism, reconstructionism, 
perennialism, and essentialism, respectively. Total of variances explained by five individual factors is approximately 50\%. Confirmatory factor analysis was applied to a structure of 40 items under 5 factors obtained as a result of explanatory factor analysis. By confirmatory factor analysis, chi-square $\left(x^{2}\right)$ value statistical significance levels $\left(x^{2} / d f=2.23\right)$ conforming to the model constituted for the scale were calculated. Moreover, other fit indices regarding the model were also shown to follow the suggested model (GFI=0.85, AGFI=0.83, RMSR $\leq 0.05$, RMSEA $\leq 0.05, \mathrm{RMR}$ and SRMR $\leq 0.08, \mathrm{CFI} \geq 0.95, \mathrm{NFI}$ and NNFI $\geq 0.95$, PGFI= 0.75). Internal consistency of EIO was tested with Cronbach's Alfa. The scale's Cronbach's Alfa coefficients vary in the range of 0.70-0.91 in subscales. Cronbach's Alfa coefficients of the scale applied to teachers and teacher candidates were found to be in the range of 0.88-0.93 and 0.86-0.94 in subscales, respectively.

EBS consists of 5 subscales and 40 items. The statements in EBS were designed in the form of 5 point likert ranking from "I certainly agree" to "I certainly disagree". There is no item scored reversely. These subscales and their associated items are as follows:

- Progressivism: It consists of items no 1-13. The highest score that can be obtained from this subscale is 65. Getting high score indicates to have progressivist educational belief.

- Existentialism: It consists of items no 14-20. The highest score that can be obtained from this subscale is 35. Getting high score indicates to have existentialist educational belief.

- Re-Constructionism: It consists of items no 21-27. The highest score that can be obtained from this subscale is 35 . Getting high score indicates to have re-constructionist educational belief.

- Perennialism: It consists of items no 28-35. The highest score that can be obtained from this subscale is 40. Getting high score indicates to have perennialist educational belief.

- Essentialism: It consists of items no 36-40. The highest score that can be obtained from this subscale is 25. Getting high score indicates to have essentialist educational belief.

\section{Analysis of Data}

"Kolmogorov-Smirnov Normal Distribution Test" was applied to see if the data from the scales shows normal distribution, the results of Kolmogorov-Smirnov Normal Distribution Test were given in table 1.

Table 1. Kolmogorov-Smirnov (KS) Normal Distribution Test Results

\begin{tabular}{lcccc}
\hline Subscales & $\mathrm{N}$ & Statistic & $\mathrm{df}$ & $\mathrm{p}$ \\
\hline Attitude Towards Multicultural Education (ATME) & 202 & 0.167 & 202 & 0.033 \\
\hline Prejusticed Attitude Towards Multicultural Education (PATME) & 202 & 0.123 & 202 & 0.000 \\
\hline Attitude Towards Democracy Education (ATDE) & 202 & 0.199 & 202 & 0.000 \\
\hline Attitude Towards Democracy (ATD) & 202 & 0.200 & 202 & 0.000 \\
\hline Attitude Towards Cultural Differences( ATCD) & 202 & 0.211 & 202 & 0.000 \\
\hline Progressivism & 202 & 0.131 & 202 & 0.000 \\
\hline Existentialism & 202 & 0.204 & 202 & 0.000 \\
\hline Re-Constructionism & 202 & 0.154 & 202 & 0.000 \\
\hline Perennialism & 202 & 0.279 & 202 & 0.000 \\
\hline Essentialism & 202 & 0.257 & 202 & 0.000 \\
\hline According
\end{tabular}

According to KS test results given in Table 1, data from 5 subscales of democracy and multicultural education attitude scale (DMEAS) and educational beliefs scale (EBS) are significant $(p<.05)$. According to these results, it was found that the data didn't show a normal distribution. Therefore, nonparametric 
Mann Whitney U Test and Kruskall Wallis Test, were used (Büyüköztürk, 2013; Kalaycl, 2005; Green and Salkind, 2008; Özdamar, 2013).

\section{FINDINGS}

Teachers' Educational Beliefs and Attitudes Towards Democracy and Multicultural Education

The "Educational Beliefs Scale" and "Democracy and Multicultural Education Attitude Scale" were used in the study. The descriptive statistics of the scales are given in table 2.

Table 2. Descriptive Satistics of "Educational Beliefs Scale" and "Democracy and Multicultural Education Attitude Scale

\begin{tabular}{|c|c|c|c|c|c|c|c|}
\hline Scales & Subscales & $\mathrm{N}$ & $\bar{X}$ & Mod & $S$ & Minimum & Maximum \\
\hline \multirow{5}{*}{ 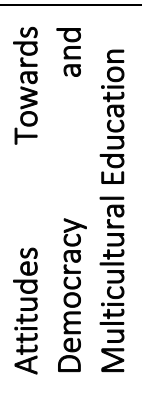 } & $\begin{array}{l}\text { Attitude Towards } \\
\text { Education (ATME) }\end{array}$ & 202 & 30,75 & 32 & 2,57 & 23 & 35 \\
\hline & $\begin{array}{l}\text { Prejusticed Attitude Towards } \\
\text { Multicultural Education (PATME) }\end{array}$ & 202 & 17,86 & 20 & 4,08 & 10 & 27 \\
\hline & $\begin{array}{ll}\text { Attitude Towards } & \text { Democracy } \\
\text { Education (ATDE) } & \end{array}$ & 202 & 20,85 & 22 & 2,72 & 14 & 25 \\
\hline & Attitude Towards Democracy (ATD) & 202 & 20,26 & 22 & 3,04 & 11 & 25 \\
\hline & $\begin{array}{lll}\text { Attitude } \quad \text { Towards } & \text { Cultural } \\
\text { Differences( } & \text { ATCD) } & \\
\end{array}$ & 202 & 13,36 & 14 & 1,28 & 9 & 15 \\
\hline \multirow{5}{*}{ 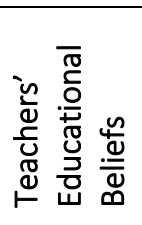 } & Progressivism & 202 & 56,24 & 56 & 4,76 & 42 & 65 \\
\hline & Existentialism & 202 & 30,97 & 31 & 1,69 & 24 & 34 \\
\hline & Re-Constructionism & 202 & 29,51 & 31 & 2,98 & 19 & 35 \\
\hline & Perennialism & 202 & 24,21 & 19 & 8,30 & 14 & 38 \\
\hline & Essentialism & 202 & 13,24 & 10 & 6,80 & 5 & 25 \\
\hline
\end{tabular}

As it is seen in Table 2, Regarding the teachers' attitudes towards democracy and multicultural education, while hile the highest score the teachers could get from ATME is 35, the average score is 30,75. The mod is 32. It was found that the teachers' attitudes towards multicultural education are positive. While the highest score the teachers could get from PATME is 27 , the average score is 17,86 . The mod is 20 . It was found that the teachers' scores of prejudiced attitudes towards multicultural education is low. High score means unprejudiced attitude since the items in this dimension were reversely encoded. While the highest score the teachers could get from ATDE is 25 , the average score is 20,85 . The mod is 22 . It was found that the teachers' attitudes towards democracy education are positive. While the highest score the teachers could get from ATD is 25 , the average score is 20,26 . The mod is 22 . It was found that the teachers' attitudes towards democracy are positive. While the highest score the teachers could get from ATCD is 15 , the average score is 13,36 . The mod is 14 . It was found that the teachers' attitudes towards cultural differences are positive.

When it comes to teachers educational beliefs, it is found that while the highest score the teachers could get from progressivism is 65 , the average score is 56,24 . The mod is 56 . Teachers' belief in progressivism was determined to be high. While the highest score the teachers could get from is 35 , the average score is 30,97 . The mod is 31 . Teachers' belief in existentialism was determined to be high. While the highest score the teachers could get from is 35 , the average score is 29,51 . The mod is 31 . Teachers' belief in reconstructionism was determined to be high. While the highest score the teachers could get from perennialism is 38 , the average score is 24,21 . The mod is 31 . It was found that the teachers' perennialist educational beliefs are at the lower level than their other educational beliefs. While the highest score the teachers could get from essentialism is 25 , the average score is 13,24 . The mod is 10 . It was found that the teachers' essentialism educational beliefs are at the lower level than their other educational beliefs. 
The Relationship Between Teachers' Educational Beliefs and Attitudes Towards Democracy and Multicultural Education

The relationship between teachers' "Educational Beliefs" and "Attitudes Towards Democracy and Multicultural Education" was investigated in the study. The relationship was investigated with "Spearman's Brown Rank Correlation Coefficient". The findings were summarized in table 3.

Table 3. Relationship Between Teachers' Educational Beliefs and Attitudes Towards Democracy and Multicultural Education

\begin{tabular}{|c|c|c|c|}
\hline Subscales & $\mathrm{N}$ & $r$ & $p$ \\
\hline ATME * Progressivism & 202 & 0,332 & $0.000^{*}$ \\
\hline ATME * Existentialism & 202 & 0,019 & 0,788 \\
\hline ATME * Re-Constructionism & 202 & 0,503 & $0,000^{*}$ \\
\hline ATME * Perennialism & 202 & $-0,002$ & 0,979 \\
\hline ATME $*$ Essentialism & 202 & $-0,028$ & 0,691 \\
\hline PATME * Progressivism & 202 & 0,014 & 0.839 \\
\hline PATME * Existentialism & 202 & $-0,184$ & $0.009 *$ \\
\hline PATME * Re-Constructionism & 202 & $-0,285$ & $0.000 *$ \\
\hline PATME * Perennialism & 202 & $-0,763$ & $0.000^{*}$ \\
\hline PATME * Essentialism & 202 & $-0,713$ & $0.000^{*}$ \\
\hline ATDE * Progressivism & 202 & 0,225 & $0.001 *$ \\
\hline ATDE $*$ Existentialism & 202 & 0,189 & $0.007^{*}$ \\
\hline ATDE $*$ Re-Constructionism & 202 & 0,221 & $0.002 *$ \\
\hline ATDE $*$ Perennialism & 202 & 0,143 & $0.043^{*}$ \\
\hline ATDE * Essentialism & 202 & $-0,083$ & 0.240 \\
\hline ATD * Progressivism & 202 & 0,205 & $0.004 *$ \\
\hline ATD $*$ Existentialism & 202 & 0,073 & 0.302 \\
\hline ATD * Re-Constructionism & 202 & 0,493 & $0.000^{*}$ \\
\hline ATD $*$ Perennialism & 202 & 0,047 & 0.520 \\
\hline ATD * Essentialism & 202 & $-0,138$ & 0.051 \\
\hline ATCD * Progressivism & 202 & 0,234 & $0.001 *$ \\
\hline ATCD * Existentialism & 202 & 0,333 & $0.000^{*}$ \\
\hline ATCD * Re-Constructionism & 202 & 0,232 & $0.001^{*}$ \\
\hline ATCD $*$ Perennialism & 202 & 0,113 & 0.110 \\
\hline ATCD * Essentialism & 202 & $-0,007$ & 0.917 \\
\hline
\end{tabular}

As it is seen in Table 3, There is a negative relationship between the teachers' attitudes towards multicultural education and perennialism and essentialism. Correlation levels between these subscales are low. There is a positive and significant relationship between ATME and progressivism and reconstructionism. Corrrelation levels between these subscales are moderate. No significant difference is found between ATME and existentialism. There is a negative and significant relationship between the teachers' prejusticed attitudes towards multicultural education and existentialism, re-constructionism, perennialism and essentialism. Correlation levels between PATME and existentialism and reconstructionism are low while correlation levels between PATME and perennialism and essentialism are high. No significant difference is found between PATME and progressivism. There is a positive and significant relationship between the teachers' attitudes towards democracy education and progressivism, existentialism, re-constructionism and perennialism. Correlation levels between these subscales are low. No significant difference is found between ATDE and essentialism. There is a positive and significant relationship between the teachers' attitudes towards democracy and progressivism and re- 
constructionism. Correlation level between ATD and progressivism is low while correlation level between ATD and re-constructionism is moderate. No significant difference is found between ATD and existentialism, perennialism and essentialism. There is a positive and significant relationship between the teachers' attitudes towards cultural differences and progressivism, existentialism and re-constructionism. Correlation levels between ATCD and progressivism and re-constructionism are low while correlation level between ATCD and existentialism is moderate. No significant difference is found between ATCD and perennialism and essentialism.

\section{Relationship Between Gender, School Stage, Seniority and Educational Beliefs}

The teachers' educational beliefs were investigated in terms of various variables. Since the data of the study didn't show a normal distribution, Mann Whitney $U$ Test and Kruskal Wallis Test were used in the study. The results of the analyses were summarized in table 4, 5, 6, 7 and 8.

Table 4. Progressivism in terms of various variables

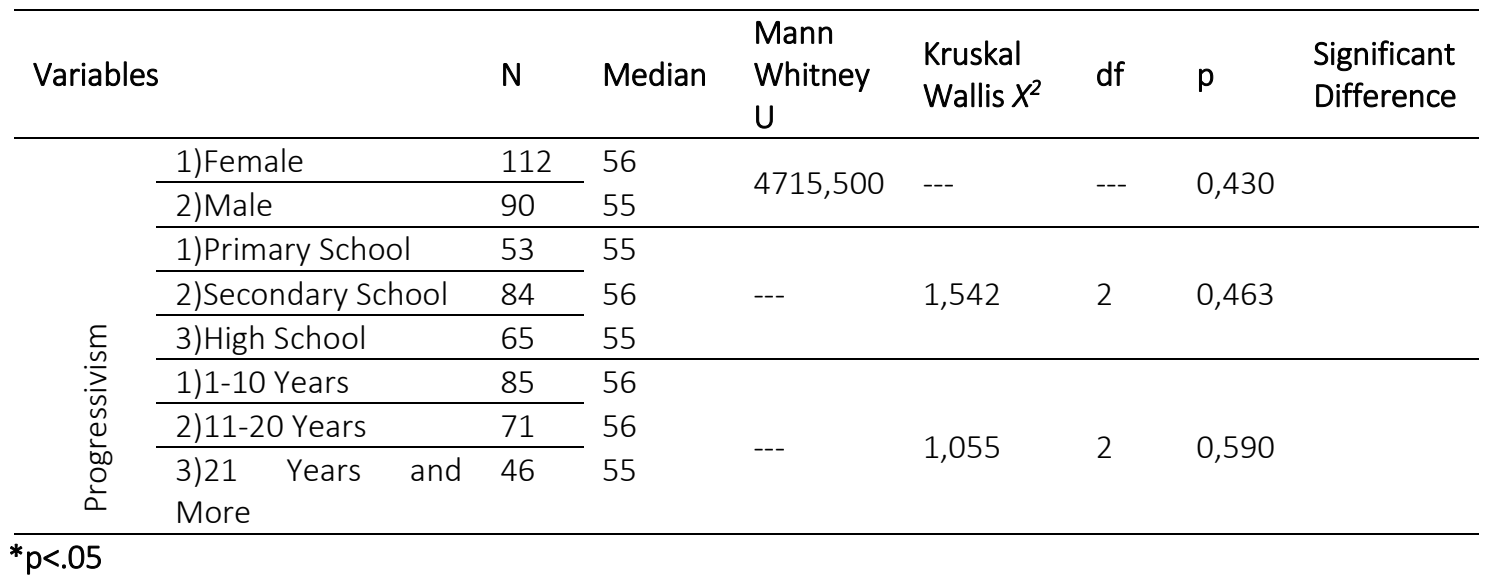

It is seen from table 4 that no significant difference was found in teachers' genders $(U=4715,500, p>.05)$, school stages $\left(X^{2}=1,542, p>.05\right)$ and seniorities $\left(X^{2}=1,055, p>.05\right)$.

Table 5. Existentialism in terms of various variables

\begin{tabular}{|c|c|c|c|c|c|c|c|c|}
\hline \multicolumn{2}{|c|}{ Variables } & \multirow{2}{*}{$\begin{array}{l}\mathrm{N} \\
112\end{array}$} & \multirow{2}{*}{$\begin{array}{l}\text { Median } \\
30\end{array}$} & \multirow{3}{*}{$\begin{array}{l}\text { Mann } \\
\text { Whitney } \\
\text { U } \\
4930,000\end{array}$} & \multirow{3}{*}{$\begin{array}{l}\text { Kruskal } \\
\text { Wallis } X^{2}\end{array}$} & \multirow{3}{*}{$\begin{array}{l}\mathrm{df} \\
--\end{array}$} & \multirow{3}{*}{$\begin{array}{l}p \\
0,784\end{array}$} & \multirow[t]{3}{*}{$\begin{array}{l}\text { Significant } \\
\text { Difference }\end{array}$} \\
\hline \multirow{8}{*}{ 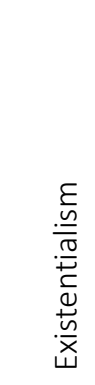 } & 1.Female & & & & & & & \\
\hline & 2.Male & 90 & 31 & & & & & \\
\hline & 1.Primary School & 53 & 30 & \multirow{3}{*}{--- } & \multirow{3}{*}{14,286} & \multirow{3}{*}{2} & \multirow{3}{*}{$0,001^{*}$} & \multirow{3}{*}{$1-3,2-3$} \\
\hline & 2.Secondary School & 84 & 30 & & & & & \\
\hline & 3.High School & 65 & 34 & & & & & \\
\hline & 1.1-10 Years & 85 & \multirow{2}{*}{$\begin{array}{l}32 \\
32\end{array}$} & \multirow{3}{*}{---} & \multirow{3}{*}{0,749} & \multirow{3}{*}{2} & \multirow{3}{*}{0,687} & \\
\hline & 2.11-20 Years & 71 & & & & & & \\
\hline & $\begin{array}{lll}.21 & \text { Years and } \\
\text { More } & & \end{array}$ & 46 & 31 & & & & & \\
\hline
\end{tabular}

${ }^{* p}<.05$

According to table 5, no significant difference was found in the teachers' genders $(U=4930,000, p>.05)$ and seniorities $\left(X^{2}=0,749, p>.05\right)$. There is a significant difference in the teachers' school stages $\left(X^{2}=14,286, p<.05\right)$. This difference is in favor of the teachers working in high schools (Median= 34). 
Table 6. Re-Constructionism in terms of various variables

\begin{tabular}{|c|c|c|c|c|c|c|c|c|}
\hline \multicolumn{2}{|c|}{ Variables } & $\mathrm{N}$ & Median & $\begin{array}{l}\text { Mann } \\
\text { Whitney U }\end{array}$ & $\begin{array}{l}\text { Kruskal } \\
\text { Wallis } X^{2}\end{array}$ & $d f$ & $p$ & $\begin{array}{l}\text { Significant } \\
\text { Difference }\end{array}$ \\
\hline \multirow{8}{*}{ 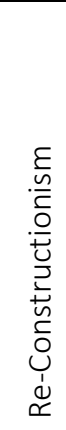 } & 1.Female & 112 & 30 & \multirow{2}{*}{4588,500} & \multirow{2}{*}{---} & \multirow{2}{*}{---} & \multirow{2}{*}{0,268} & \\
\hline & 2.Male & 90 & 31 & & & & & \\
\hline & 1.Primary School & 53 & 29 & \multirow{3}{*}{---} & \multirow{3}{*}{12,532} & \multirow{3}{*}{2} & \multirow{3}{*}{$0,002 *$} & \multirow{3}{*}{$2-3$} \\
\hline & $\begin{array}{l}\text { 2.Secondary } \\
\text { School }\end{array}$ & 84 & 31 & & & & & \\
\hline & 3.High School & 65 & 28 & & & & & \\
\hline & 1.1-10 Years & 85 & \multirow{3}{*}{$\begin{array}{l}30 \\
30 \\
30\end{array}$} & \multirow{3}{*}{---} & \multirow{3}{*}{2,673} & \multirow{3}{*}{2} & \multirow{3}{*}{0,263} & \\
\hline & 2.11-20 Years & 71 & & & & & & \\
\hline & $\begin{array}{l}3.21 \text { Years and } \\
\text { More }\end{array}$ & 46 & & & & & & \\
\hline
\end{tabular}

According to table 6, no significant difference was found in teachers' genders $(U=4588,500, p>.05)$, and seniorities $\left(X^{2}=2,673, p>.05\right)$. It is also seen that there is a significant difference in teachers' school stages $\left(X^{2}=12,532, p<.05\right)$. This difference is in favor of the teachers working in secondary schools (Median= 31 ).

Table 7. Perennialism in terms of various variables

\begin{tabular}{|c|c|c|c|c|c|c|c|c|}
\hline \multicolumn{2}{|c|}{ Variables } & $\mathrm{N}$ & Median & $\begin{array}{l}\text { Mann } \\
\text { Whitney } \\
\text { U }\end{array}$ & $\begin{array}{l}\text { Kruskal } \\
\text { Wallis } \\
X^{2}\end{array}$ & $d f$ & $p$ & $\begin{array}{l}\text { Significant } \\
\text { Difference }\end{array}$ \\
\hline \multirow{9}{*}{ 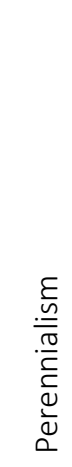 } & 1.Female & 112 & 22 & \multirow{2}{*}{3894,500} & \multirow{2}{*}{--- } & \multirow{2}{*}{---} & \multirow{2}{*}{$0,005^{*}$} & \multirow{2}{*}{$1-2$} \\
\hline & 2.Male & 90 & 26 & & & & & \\
\hline & 1.Primary & 53 & \multirow{3}{*}{$\begin{array}{l}24 \\
24\end{array}$} & \multirow{4}{*}{---} & \multirow{4}{*}{4,062} & \multirow{4}{*}{2} & \multirow{4}{*}{0,131} & \\
\hline & School & & & & & & & \\
\hline & $\begin{array}{l}\text { 2.Secondary } \\
\text { School }\end{array}$ & 84 & & & & & & \\
\hline & 3.High School & 65 & 26 & & & & & \\
\hline & $1.1-10$ Years & 85 & \multirow{3}{*}{$\begin{array}{l}20 \\
24 \\
32\end{array}$} & \multirow{3}{*}{--- } & \multirow{3}{*}{46,135} & \multirow{3}{*}{2} & \multirow{3}{*}{$0,000 *$} & \multirow{3}{*}{$1-3$} \\
\hline & 2.11-20 Years & 71 & & & & & & \\
\hline & $\begin{array}{l}3.21 \text { Years and } \\
\text { More }\end{array}$ & 46 & & & & & & \\
\hline
\end{tabular}

According to table 7, no significant difference was found in the teachers' school stages $\left(X^{2}=4,062, p>.05\right)$. There is a significant difference in the teachers' genders $(U=3894,500, p<.05)$. This difference is in favor of the male teachers (Median= 26). There is a significant difference in the teachers' seniorities $\left(X^{2}=46,135\right.$, $\mathrm{p}<.05)$. This difference is in favor of the teachers with seniority of 21 years and more (Median= 32). 
Table 8. Essentialism in terms of various variables

\begin{tabular}{|c|c|c|c|c|c|c|c|c|}
\hline \multicolumn{2}{|c|}{ Variables } & $\mathrm{N}$ & Median & $\begin{array}{l}\text { Mann } \\
\text { Whitney U }\end{array}$ & $\begin{array}{l}\text { Kruskal } \\
\text { Wallis } X^{2}\end{array}$ & df & $p$ & $\begin{array}{l}\text { Significant } \\
\text { Difference }\end{array}$ \\
\hline \multirow{8}{*}{ 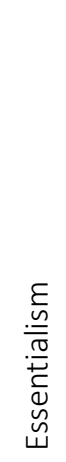 } & 1.Female & 112 & 12 & \multirow{2}{*}{3801,500} & \multirow{2}{*}{---} & \multirow{2}{*}{---} & \multirow{2}{*}{$0,003 *$} & \multirow{2}{*}{$1-2$} \\
\hline & 2.Male & 90 & 15 & & & & & \\
\hline & $\begin{array}{l}\text { 1.Primary } \\
\text { School }\end{array}$ & 53 & 13 & \multirow{3}{*}{--- } & \multirow{3}{*}{4,088} & \multirow{3}{*}{2} & \multirow{3}{*}{0,145} & \\
\hline & $\begin{array}{l}\text { 2.Secondary } \\
\text { School }\end{array}$ & 84 & 11 & & & & & \\
\hline & 3.High School & 65 & 14 & & & & & \\
\hline & 1.1-10 Years & 85 & \multirow{3}{*}{$\begin{array}{l}11 \\
13 \\
19\end{array}$} & \multirow{3}{*}{---} & \multirow{3}{*}{35,678} & \multirow{3}{*}{2} & \multirow{3}{*}{$0,000^{*}$} & \multirow{3}{*}{$1-3$} \\
\hline & 2.11-20 Years & 71 & & & & & & \\
\hline & $\begin{array}{l}3.21 \text { Years and } \\
\text { More }\end{array}$ & 46 & & & & & & \\
\hline
\end{tabular}

According to table 8, no significant difference was found in the teachers' school stages $\left(X^{2}=4,088, p>.05\right)$. There is a significant difference in the teachers' genders $(U=3801,500, p<.05)$. This difference is in favor of the male teachers (Median= 15). There is a significant difference in the teachers' seniorities $\left(X^{2}=35,678\right.$, $\mathrm{p}<.05)$. This difference is in favor of the teachers with seniority of 21 years and more (Median= 19).

\section{Relationship Between Gender, School Stage, Seniority and Democracy-Multicultural Educational Attitudes}

The teachers' educational attitudes towards democracy and multicultural education were investigated in terms of various variables in the study. Since the data of the study didn't show a normal distribution, Mann Whitney $U$ Test and Kruskal Wallis Test were used in the study. The results of the analyses were summarized in table 9, 10, 11, 12 and 13.

Table 9. Attitude Towards Multicultural Education in Terms of Various Variables (ATME)

\begin{tabular}{|c|c|c|c|c|c|c|c|c|}
\hline Variables & & $\mathrm{N}$ & Median & $\begin{array}{l}\text { Mann } \\
\text { Whitney } \\
\text { U }\end{array}$ & $\begin{array}{l}\text { Kruskal } \\
\text { Wallis } \\
X^{2}\end{array}$ & $d f$ & $p$ & $\begin{array}{l}\text { Significant } \\
\text { Differences }\end{array}$ \\
\hline \multirow{4}{*}{ 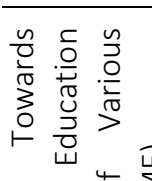 } & 1.Female & 112 & 30 & \multirow{2}{*}{3942,500} & \multirow{2}{*}{--- } & \multirow{2}{*}{---} & \multirow{2}{*}{$0,007 *$} & \multirow{2}{*}{$1-2$} \\
\hline & 2.Male & 90 & 32 & & & & & \\
\hline & 1.Primary School & 53 & 30 & \multirow{3}{*}{---} & \multirow{3}{*}{10,798} & \multirow{3}{*}{2} & \multirow{3}{*}{$0,005^{*}$} & \multirow{3}{*}{$2-3$} \\
\hline & 2.SecondarySchool & 84 & 32 & & & & & \\
\hline \multirow{4}{*}{ 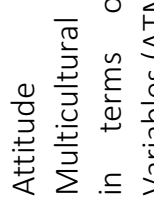 } & 3.High School & 65 & 29 & & & & & \\
\hline & 1.1-10 Years & 85 & 32 & \multirow{3}{*}{---} & \multirow{3}{*}{9,149} & \multirow{3}{*}{2} & \multirow{3}{*}{$0,010^{*}$} & \multirow{3}{*}{$1-3$} \\
\hline & 2.11-20 Years & 71 & 31 & & & & & \\
\hline & $\begin{array}{l}3.21 \text { Years and } \\
\text { More }\end{array}$ & 46 & 29 & & & & & \\
\hline
\end{tabular}

$* p<.05$

It is seen from table 9 that there is a significant difference in the teachers' genders $(U=3942,500, p<.05)$ in their ATME. This difference is in favor of the male teachers (Median= 32). There is a significant difference in the teachers' school stages $\left(X^{2}=10,798, p<.05\right)$. This difference is in favor of the teachers working in secondary schools (Median= 32). It is seen that there is a significant difference in the teachers' seniorities $\left(X^{2}=9,149, p<.05\right)$. This difference is in favor of the teachers with seniority of $1-10$ years (Median= 32). 
Table 10. Prejusticed attitude towards multicultural education in terms of various variables (PATME)

\begin{tabular}{|c|c|c|c|c|c|c|c|}
\hline Variables & $\mathrm{N}$ & Median & $\begin{array}{l}\text { Mann } \\
\text { Whitney U }\end{array}$ & $\begin{array}{l}\text { Kruskal } \\
\text { Wallis } X^{2}\end{array}$ & df & $\mathrm{p}$ & $\begin{array}{l}\text { Significant } \\
\text { Difference }\end{array}$ \\
\hline$\subseteq \cong$ 1. Female & 112 & 18 & \multirow{2}{*}{4773,500} & \multirow{2}{*}{--- } & \multirow{2}{*}{---} & \multirow{2}{*}{0,517} & \\
\hline 2.Male & 90 & 17 & & & & & \\
\hline 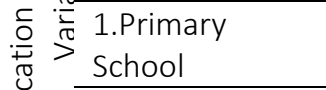 & 53 & 19 & \multirow{3}{*}{--- } & \multirow{3}{*}{4,124} & \multirow{3}{*}{2} & \multirow{3}{*}{0,146} & \\
\hline 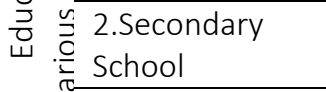 & 84 & 18 & & & & & \\
\hline $\bar{\pi}^{>}$3. High School & 65 & 17 & & & & & \\
\hline$\pm \stackrel{4}{0} 1.1-10$ Years & 85 & 20 & \multirow{3}{*}{---} & \multirow{3}{*}{34,479} & \multirow{3}{*}{2} & \multirow{3}{*}{0,000} & \multirow{3}{*}{$1-3,2-3$} \\
\hline$\overline{\underline{U}} \backsim 2.11-20$ Years & 71 & 19 & & & & & \\
\hline 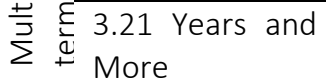 & 46 & 15 & & & & & \\
\hline
\end{tabular}

According to table 10 , no significant difference was found in the teachers' genders $(U=4773,500, p>.05)$ and school stages $\left(X^{2}=4,124, p>.05\right)$. It is seen that there is a significant difference in the teachers' seniorities $\left(X^{2}=34,479, p<.05\right)$. It is seen that there is a significant difference in the teachers' seniorities $\left(X^{2}=9,149, p<.05\right)$. This difference is in favor of the teachers with seniority of $1-10$ years (Median= 20).

Table 11. Attitude towards democracy education in terms of various variables (ATDE)

\begin{tabular}{|c|c|c|c|c|c|c|c|c|c|}
\hline \multicolumn{2}{|l|}{ Variables } & $\mathrm{N}$ & Median & $\begin{array}{l}\text { Mann } \\
\text { Whitney } \\
\text { U }\end{array}$ & $\begin{array}{l}\text { Kruskal } \\
X^{2}\end{array}$ & Wallis & $d f$ & $p$ & $\begin{array}{l}\text { Significant } \\
\text { Difference }\end{array}$ \\
\hline \multirow{3}{*}{ 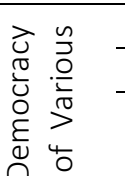 } & 1.Female & 112 & 21 & \multirow{2}{*}{4904,500} & \multirow{2}{*}{--- } & \multirow{2}{*}{\multicolumn{2}{|c|}{--- }} & \multirow{2}{*}{0,740} & \\
\hline & 2.Male & 90 & 20 & & & & & & \\
\hline & $\begin{array}{l}\text { 1.Primary } \\
\text { School }\end{array}$ & 53 & 20 & \multirow{3}{*}{--- } & \multirow{3}{*}{2,523} & \multirow{3}{*}{\multicolumn{2}{|c|}{2}} & \multirow{3}{*}{0,215} & \\
\hline \multirow{2}{*}{ 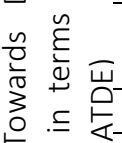 } & $\begin{array}{l}\text { 2.Secondary } \\
\text { School }\end{array}$ & 84 & 21 & & & & & & \\
\hline & 3.High School & 65 & 20 & & & & & & \\
\hline \multirow{3}{*}{ 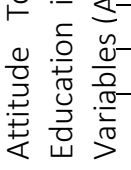 } & $1.1-10$ Years & 85 & 21 & \multirow{3}{*}{--- } & \multirow{3}{*}{1,067} & \multirow{3}{*}{\multicolumn{2}{|c|}{2}} & \multirow{3}{*}{0,586} & \\
\hline & 2.11-20 Years & 71 & 21 & & & & & & \\
\hline & $\begin{array}{l}3.21 \text { Years and } \\
\text { More }\end{array}$ & 46 & 22 & & & & & & \\
\hline
\end{tabular}

According to table 11, no significant difference was found in the teachers'genders $(U=4904,500, p>.05)$, school stages $\left(X^{2}=2,523, p>.05\right)$ and seniorities $\left(X^{2}=1,067, p>.05\right)$. 
Table 12. Attitude towards democracy education in terms of various variables (ATD)

\begin{tabular}{|c|c|c|c|c|c|c|c|c|c|}
\hline \multicolumn{2}{|c|}{ Variables } & $\mathrm{N}$ & Median & $\begin{array}{l}\text { Mann } \\
\text { Whitney } \\
U\end{array}$ & $\begin{array}{l}\text { Kruskal } \\
X^{2}\end{array}$ & Wallis & $d f$ & $p$ & $\begin{array}{l}\text { Significant } \\
\text { Difference }\end{array}$ \\
\hline \multirow{3}{*}{ 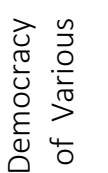 } & 1.Female & 112 & 20 & \multirow{2}{*}{4823,000} & \multirow{2}{*}{---} & \multirow{2}{*}{\multicolumn{2}{|c|}{---}} & \multirow{2}{*}{0,595} & \\
\hline & 2.Male & 90 & 20 & & & & & & \\
\hline & $\begin{array}{l}\text { 1.Primary } \\
\text { School }\end{array}$ & 53 & 20 & \multirow{3}{*}{--- } & \multirow{3}{*}{3,118} & \multirow{3}{*}{\multicolumn{2}{|c|}{2}} & \multirow{3}{*}{0,192} & \\
\hline \multirow{2}{*}{ 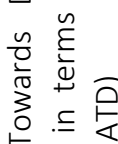 } & $\begin{array}{l}\text { 2.Secondary } \\
\text { School }\end{array}$ & 84 & 21 & & & & & & \\
\hline & 3.High School & 65 & 20 & & & & & & \\
\hline \multirow{3}{*}{ 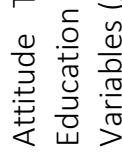 } & 1.1-10 Years & 85 & 20 & \multirow{3}{*}{---} & \multirow{3}{*}{4,570} & & & \multirow{3}{*}{0,102} & \\
\hline & 2.11-20 Years & 71 & 20 & & & & 2 & & \\
\hline & $\begin{array}{l}3.21 \text { Years and } \\
\text { More }\end{array}$ & 46 & 19 & & & & & & \\
\hline
\end{tabular}

According to table 12, no significant difference was found in the teachers' genders $(U=4823,000, p>.05)$, school stages $\left(X^{2}=3,118, p>.05\right)$ and seniorities $\left(X^{2}=4,570, p>.05\right)$.

Table 13. Attitude towards cultural differences in terms of various variables (ATCD)

\begin{tabular}{|c|c|c|c|c|c|c|c|c|c|}
\hline \multicolumn{2}{|c|}{ Variables } & $N$ & Median & $\begin{array}{l}\text { Mann } \\
\text { Whitney } \\
U\end{array}$ & $\begin{array}{l}\text { Kruskal } \\
X^{2}\end{array}$ & Wallis & df & $p$ & $\begin{array}{l}\text { Significant } \\
\text { Difference }\end{array}$ \\
\hline \multirow{4}{*}{ 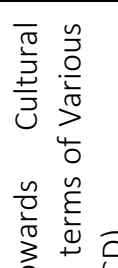 } & 1.Female & 112 & 13 & \multirow{2}{*}{4955,500} & \multirow{2}{*}{---} & \multirow{2}{*}{\multicolumn{2}{|c|}{---}} & \multirow{2}{*}{0,833} & \\
\hline & 2.Male & 90 & 13 & & & & & & \\
\hline & $\begin{array}{l}\text { 1.Primary } \\
\text { School }\end{array}$ & 53 & 13 & \multirow{3}{*}{---} & \multirow{3}{*}{5,677} & & \multirow{3}{*}{2} & \multirow{3}{*}{0,059} & \\
\hline & $\begin{array}{l}\text { 2.Secondary } \\
\text { School }\end{array}$ & 84 & 14 & & & & & & \\
\hline \multirow{2}{*}{\multicolumn{2}{|c|}{$\vdash}}$. & 65 & 13 & & & & & & \\
\hline & & 85 & 14 & \multirow{3}{*}{--} & \multirow{3}{*}{2,691} & & \multirow{3}{*}{2} & \multirow{3}{*}{0,260} & \\
\hline \multirow{2}{*}{\multicolumn{2}{|c|}{ 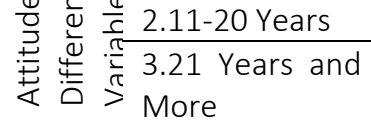 }} & 71 & 14 & & & & & & \\
\hline & & 46 & 15 & & & & & & \\
\hline
\end{tabular}

According to table 13 , no significant difference was found in the teachers'genders $(U=4955,500, p>.05)$, school stages $\left(X^{2}=5,677, p>.05\right)$ and seniorities $\left(X^{2}=2,691, p>.05\right)$.

\section{DISCUSSION \& CONCLUSION}

The purpose of the study is to determine the relationship between teachers' educational beliefs and attitudes towards democracy and multicultural education according to some variables. In terms of educational beliefs, the teachers prefer progressivism, existentialism, re-constructionalism, perennialism and essentialism respectively. It was found that while the teachers adopted essentialism educational belief at a low level, they adopted other educational beliefs at a high level. Similarly, the educational philosophy that teachers adopted least in the studies by Doğanay and Sarı (2003) and Duman (2008) is perennialism. On the other hand, the educational philosophy that teachers adopted least in the study by Tekin and Üstün (2008) is existentialism.

The findings show that teachers adopt modern educational philosophies most, which suggests that teachers have a positive attitude towards a system of education in which students can improve 
themselves, gain critical and reflective thinking skills, make researches and have the ability to analyze and evaluate.

It was found in the study on preservice teachers by Ekiz (2007) that the most adopted educational philosophies are progressivism and re-constructionism, and the least adopted educational philosophies are essentialism and perennialism. It is remarkable that existentialism, as well as progressivism and reconstructionism, are those adopted at a high level. The findings are consistent with the study.

It can be considered positive that educational beliefs adopted by the teachers at the highest level are existentialism and progressivism. Both philosophies oppose conventional education's mentality which defends teacher-centered strict discipline and the formation of an undemocratic learning environment where students are passive.

Although the teacher' opinions in essentialism and perennialism subdimensions differ according to gender in the current study; teachers' educational beliefs don't differ according to gender in the studies by Doğanay and Sarı, (2003); Türkeli, (2011); Altınkurt et.al., (2012); Karadağ et.al., (2009); Ilgaz, Bülbül and Çuhadar, (2013).

There is a significant difference according to school stage variable in re-constructionism subdimension. It was found that the secondary school teachers showed a positive attitude towards re-constructionism, which can help students gain a democratic personality. Besides, it was seen that school stage variable also made a significant difference in the existentialism subdimension. The high school teachers adopted existentialism philosophy at a higher level. This suggests that the teachers have a positive attitude towards high school students who are becoming an individual with distinctive personality. In fact, according to existentialist philosophy, the objective of education is to accept individuals as they are.

The teachers' educational beliefs differ in perennialism and essentialism subdimensions, according to school stage variable. The difference in teachers' perennialist educational beliefs is in favor of the teachers with the seniority of 21 years and more when compared to those with the seniority of 1-10 years. The difference in teachers' essentialist educational beliefs is in favor of the teachers with the seniority of 21 years and more when compared to those with the seniority of 1-10 years. Similarly, it was found in the study by Doğanay and Sarı (2003) that the teachers working for longer duration adopted idealism and realism philosophies at a higher levels. The reason of that can be burnout feeling and decrease in their expectations for future.

It is remarkable in the study that the teachers' beliefs towards educational philosophies except essentialism decrease with increasing of seniority. The reason of that can be the seniority stage the teachers are involved in. Young teachers' beliefs towards modern educational philosophies is at a higher level. It is noteworthy that the teachers with lower seniority play a guide role; show an attitude which directs students to independent thinking and concentrates on individualist learning rather than being an authoritative figure in the classroom.

Educational beliefs-related results are evaluated in general, teachers' progressivist and exisentialist educational beliefs can be considered positively. Sönmez (2002) underlines that although Turkish educational system fundamentally was constituted by progressivism mentality in post Republic period, educational practices were actualized on the basis of perennialism and essentialism. In this context, new studies can be conducted to turn educational beliefs into behaviors in order to renew and improve system of education. The educational approach in theory create an environment where individual is not cared; content is given importance instead of comprehension and interdisciplinary interaction is lack. The teachers' attitudes towards democracy and multicultural education differ in the subdimension of attitude 
towards multicultural education according to gender variable. However, no significant difference was found according to gender variable in the study by Aydin, H., Acar, F. and Toraman, Ç. (2016).

The teachers' attitudes towards democracy and multicultural education differ according to school stage variable, only in the subdimension of attitude towards multicultural education. The difference is in favor of the teachers working in secondary schools. It is an expected result that the secondary school teachers adopting re-constructionism philosophy at the highest level have a positive attitude towards multicultural education.

The teachers' prejudiced attitudes towards multicultural education and attitudes towards multicultural education differ according to school stage variable. The teachers' prejudiced attitudes towards multicultural education, having the seniority of 21 years and more, are at a higher level than those having the seniority of 1-10 years, and 11-20 years. It is seen that the more the teachers' seniority levels increase, the more their attitudes towards multicultural education become negative. This can be interpreted in the way that the teachers with higher seniority levels act under the influence of conventional educational mentality. Likewise, the difference in teachers' attitudes towards multicultural education is in favor of the teachers with the seniority of 1-10 years when compared to those with the seniority of 21 years and more. It can be concluded that the teachers with lower seniority levels are more aware of socio-cultural and personal differences. Similar to the results of the current study, it was concluded in the study by Aydin, H. Acar, F. and Toraman, Ç. (2016) that older teachers are less aware of the importance of multicultural education than younger teachers.

When the relationship between educational beliefs and democracy and multicultural education was investigated, it was seen that there is a negative relationship between the teachers' attitudes towards multicultural education and perennialism and essentialism. This can be interpreted as a natural reflection of perennialism and essentialism mentalities that assert an unchangeable and universal educational belief.

It was determined that the teachers' educational beliefs for existentialism and re-constructionism have a negative relationship with their prejudiced attitudes towards multicultural education, and a positive relationship with democracy education. Similarly, there is a positive and significant relationship between the teachers' attitudes towards democracy and progressivism and re-constructionism. There is also a positive and significant relationship between the teachers' attitudes towards cultural differences and progressivism, existentialism and re-constructionism. These results can be interpreted in the way that the teachers, who put individual's interest, need, and skills in the center of educational process, emphasize on equality in opportunity and social change, adopt modern educational philosophies, give importance to democracy in education and think that continous changes and developments are necessary in education. In terms of the relationship between democracy and modern educational philosophies, Sönmez (2002) underlined that progressivism suggests that the aim of education is to train individuals who adopt democracy.

\section{Suggestions and Future Research}

Determining significant relationships between educational beliefs and democracy and multicultural education points out the importance of raising awareness of these values in the field of education. A further study can be conducted on the educational philosophies of teachers in different age groups that have not been investigated in the present study. A study on both educational beliefs and attitudes towards democracy and multicultural education can be conducted with preservice teachers. The studies can be conducted on larger study groups in order to conduct more comprehensive studies on educational beliefs and attitudes towards democracy and multicultural education. More findings can be obtained by 
quantitative data collection methods. Seminars and in-service trainings can be provided to teachers about the importance of both educational beliefs and democracy and multicultural education.

\section{References}

Ameny-Dixon, G.M. (2004). Why multicultural education is more important in higher education now than ever: A global perspective. International Journal of Scholarly Academic Intellectual Diversity, 8(1), 1-9.

Aydin, H. Acar, F ve Toraman, Ç. (2016). Sınıf Öğretmenlerinin Demokrasi ve Çokkültürlü Eğitime iliş̧kin Bilgi Düzeyleri ve Tutumları (Sözlü Bildiri). II. Uluslararası Öncü Öğretmenler Zirvesi, 15-17 Temmuz 2016, Üsküp, Makedonya

Banks, J.A. (2012) Ethnic studies, citizenship education, and the public good. Intercultural Education, 23(6), 467-474.

Banks, J.A. (2013). An Introduction to Multicultural Education (5th Edition). Boston, MA: Pearson Publications.

Balcı, A. (2010). Açıklamalı Eğitim Yönetimi Terimleri Sözlüğü (2. Baskı). Ankara: Pegem Yayınları.

Brauner, C. J. ve Burns, H. W. (1982). Eğitim Felsefesi. (Çev. S. Büyükdüvenci). Ankara Üniversitesi Eğitim Bilimleri Fakültesi Dergisi, 15 (2), 291-298.

Büyükkaragöz, S. (1990). Demokrasi Eğitimi. Türk Demokrasi Vakfı Yayınları. Ankara.

Büyükkaragöz, S. S. ve Çivi, C. (1998). Genel Öğretim Metotları (8. Baskı). Konya: Öz Eğitim Yayınları.

Büyüköztürk, Ş. (2013). Sosyal Bilimler İçin Veri Analizi El Kitabı. Ankara: Pegema Yayınları.

Collins, J. W. and O'Brien, N. P. (2003). The Greenwood Dictionary of Education. Greenwood Press. Westport, USA

Demirel, Ö. (2006). Kuramdan Uygulamaya Eğitimde Program Geliştirme (9. Baskı). Ankara: Pegem Akademi Yayıncılık.

Doğanay, A. ve Sarı, M. (2003). İlköğretim Öğretmenlerinin Sahip Oldukları Eğitim Felsefelerine İlişkin Algıların Değerlendirilmesi-Öğretmenlerin Eğitim Felsefeleri. Türk Eğitim Bilimleri Dergisi, 1 (3), 321-337.

Dörnyei, Z. (2007). Research methods in applied linguistics. New York: Oxford University Press.

Duman, B. (2008). Öğrencilerin Benimsedikleri Eğitim Felsefeleriyle Kullanıldıkları Öğrenme Strateji ve Öğrenme Stillerinin Karşılaştırılması. Çukurova Üniversitesi Sosyal Bilimler Enstitüsü Dergisi, 17(1), 203-224.

Ekiz, D. (2007). Öğretmen Adaylarının Eğitim Felsefesi Akımları Hakkında Görüşlerinin Farklı Programlar Açısından İncelenmesi. Ondokuz Mayıs Üniversitesi Eğitim Fakültesi Dergisi, 24, 1-12.

Green, S.B. \& Salkind, N.J (2008). Using SPSS for Window and Macintosh: Analyzing and Understanding Data (10th Edition.). Pearson Education Ltd.

Gözütok, F. D. (2007). Öğretim Illke ve Yöntemleri (2. Baskı). Ankara : Ekinoks Kitabevi. 
Ilgaz, G., Bülbül, T. ve Çuhadar, C. (2013). Öğretmen Adaylarının Eğitim İnançları ile Öz-Yeterlik Algıları Arasındaki İlişkinin İncelenmesi. Abant İzzet Baysal Üniversitesi Eğitim Fakültesi Dergisi, 13 (1), 5065.

Kalaycı, Ş. (2005). SPSS uygulamalı çok değişkenli istatistik teknikleri. Ankara: Asil Yayın Dağıtım.

Karadağ, E., Baloğlu, N. ve Kaya, S. (2009). Okul Yöneticilerinin Eğitim Felsefesi Akımlarını Benimseme Düzeylerine İlişkin Ampirik Bir Çalışma. Kaygı-Uludağ Üniversitesi Felsefe Dergisi, 12, 181-200.

Özdamar, K. (2013). Paket Programlar ile İstatistiksel Veri Analizi (9. Baskı). Eskişehir: Nisan Kitabevi.

Gay, G. (1994). The essence of learning. Bloomington, IN: Kappa Delta Pi.

Haney, J., Czerniak, C., \& Lumpe, A. (2003). Constructivist Beliefs about the Science Classroom Learning Environment: Perspectives from Teachers, Administrators. School Science and Mathematics, 103 (8), 366-377.

Karasar, N. (2009). Bilimsel araştırma yöntemi. Ankara: Nobel Yayınevi.

Kağıtçıbaşı, Ç. (2006). Yeni Insan ve Insanlar. İstanbul: Evrim Yayıncılık.

Kridel, C. (2010). Encyclopedia of Curriculum Studies. Thousand Oaks, CA: Sage Publication.

Sharma, S. (2005) Multicultural Education: Teachers' Perceptions and Preparation. Journal of Collage Teaching and Learning, 2 (5), 53-64.

Şişman, M. (2010). Eğitim Bilimine Giriş (7. Baskı). Ankara: Pegem Yayınları.

Sönmez, V. (2002). Eğitim Felsefesi. Ankara: Anı Yayıncılık.

Şişman, M. (2000). Öğretmenlik Mesleğine Giriş. Ankara: Pegem Akademi Yayıncılık.

Şişman, M. (2002). Eğitimde mükemmellik arayışı: Etkili okullar. Ankara: Pegem Akademi Yayıncılık.

Tavşancıl, E. (2005). Tutumların Ölçülmesi ve SPSS ile Veri Analizi. Ankara: Nobel Yayıncılık.

Tekin, S. ve Üstün, A. (2008). Amasya Eğitim Fakültesi Öğretmen Adaylarının Eğitim Süreci Hakkındaki Felsefi Tercihlerinin Tespiti. Selçuk Üniversitesi Ahmet Keleşoğlu Eğitim Fakültesi Dergisi, 25, 145158.

Toraman, Ç., Acar, F., and Aydin, H. (2015). Primary School Teachers' Attitudes and Knowledge Levels on Democracy and Multicultural Education: A Scale Development Study. Review of Research and Social Intervention, 49, 41-58, ISSN: 1583-3410 (print), ISSN: 1584-5397 (electronic)

Türkeli, A. (2011). Beden Eğitimi Öğretmenlerinin Eğitim Felsefeleri ve Teknolojiye Karşı Tutumları. Yayımlanmamış yüksek lisans tezi. Ankara: Gazi Üniversitesi Eğitim Bilimleri Enstitüsü.

Ünlü, ì. ve Örten, H. (2013). Ögretmen Adaylarının Çokkültürlülük ve Çokkültürlü Eğitime Yönelik Algılarının İncelenmesi. Dicle Üniversitesi, Ziya Gökalp Eğitim Fakültesi Dergisi, 21, 287-302.

Varış, F. (1994). Eğitim Bilimine Giriş. Ankara: Ankara Üniversitesi Eğitim Bilimleri Fakültesi Yayını.

Yayla, A. (2009). Eğitimin Felsefi Temelleri. H. B. Memduhoğlu ve K. Yılmaz (Ed.), Eğitim Bilimine Giriş içinde (s. 19-43). Ankara: Pegem Akademi Yayıncılık.

Yeşil, R. (2002). Okul ve Ailede Insan Hakları ve Demokrasi Eğitimi. Ankara: Nobel Yayın Dağıtım. 
Yılmaz, K., Altınkurt, Y. ve Çokluk, Ö. (2011). Eğitim İnançları Ölçeğinin Geliştirilmesi: Geçerlik ve Güvenirlik Çalışması. Kuram ve Uygulamada Eğitim Bilimleri, 11 (1), 335-350.

Yoon, Hi-W. (2012). Why is multicultural education important and How is diversity a benefit to educators. Education Alliance Magazine, 5, 5-7. 